\begin{tabular}{c|c|c}
\hline JURNAL PENELITIAN KESMASY & VOL. 1 NO. 2 & $\begin{array}{c}\text { EDITION: NOVEMBER 2018 - } \\
\text { APRIL 2019 }\end{array}$ \\
\hline \multirow{2}{*}{ RECEIVED: 6 Februari 2019} & http://ejournal.delihusada.ac.id/index.php/JPKSY & ACCEPTED: 20 MARET 2019 \\
\cline { 2 - 3 } & REVISED: 18 FEBRUARI 2019 & ACE
\end{tabular}

\title{
DAMPAK TERPAPAR TOLUENA TERHADAP KADAR ASAM HIPURAT URIN PADA PEKERJA PENGECATAN OVEN OTOMOTIF
}

\author{
Adi Rahmat \\ Politeknik Kesehatan Medan \\ adi.rahmat@gmail.com
}

\begin{abstract}
Toluene can be detected through urine and blood, in toluene urine can be examined through hypuric acid. Examination of hypuric acid in urine is one type of biological monitoring that is important in initiating and measuring toluene exposure in the workforce. This research was conducted at two Acapella workshops for automotive oven painting with a sample of 12 workers. The results showed that attention to occupational health and safety programs, especially efforts to prevent the occurrence of side effects due to exposure to toluene vapor was still low, the average level of urine hypuric acid in the workers in the morning was still at the normal threshold $(1.68 \mathrm{~g} / \mathrm{g})$, and increases in the afternoon $(5.03 \mathrm{~g} / \mathrm{g})$ even though there are some workers who have levels that are far above the normal threshold value, Variables of age and years of service have a role in determining the level of hypuric acid, where the working period has a greater role than the age variable.
\end{abstract}

Keyword: Toluena, kadar asam hipurat, tes urin.

\section{PEndahuluan}

Toluena adalah suatu hidrokarbon $\left(\mathrm{C}_{7} \mathrm{H}_{8}\right)$ yang digunakan sebagai bahan pelarut cat, bahan kimia, farmasi, dan karet serta juga digunakan sebagai keperluan bahan mentah utama dalam sintesis bahan pewarna sakarin dan lain-lain. Toluena ditemukan dalam bensin, cat akrilik, pernis, bahan pengencer cat, perekat karet, lem pesawat udara, dan semir sepatu. Pada suhu kamar toluena adalah suatu cairan tidak berwarna, mudah menguap dan manis (Martin, 2001). Pemakaian toluena di Indonesia semakin meningkat jumlahnya dari tahun ke tahun dan berdasarkan data dari Biro Pusat Statistik dan Departemen Perindustrian dan Perdagangan Republik Indonesia pada tahun 1990 terpakai $44.061 .498 \mathrm{~kg}$ dan tahun 1997 terpakai $93.361 .061 \mathrm{~kg}$ (BPS, 1996).

Toluena dapat menimbulkan keracunan akut pada susunan saraf pusat, dengan tandatanda rasa pusing, rasa sakit kepala, rasa kantuk dan tanda-tanda depresi susunan saraf pusat. Toluena masuk ke dalam tubuh tenaga kerja biasanya melalui inhalasi, sedangkan absorbsi atau penyerapan melalui kulit biasanya sedikit. Penyerapan melalui mulut biasanya terjadi karena faktor ketidaksengajaan atau bisa juga karena kecelakaan yaitu sebanyak lebih kurang $20 \%$, toluena yang terinhalasi biasanya akan dikeluarkan dari tubuh melalui pernapasan dalam bentuk utuh dan lebih kurang $80 \%$ setelah mengalami metabolisme akan diekskresi dalam urin sebagai asam hipurat dan kurang dari $1 \%$ lainnya diekskresikan dalam urin sebagai Q-kresol dan toluena utuh. Toluena pada tahun 50 ppm sampai 200 ppm dapat menimbulkan keracunan akut pada susunan saraf pusat dengan tanda-tanda adanya rasa pusing, rasa sakit kepala dan rasa kantuk. Pada konsentrasi 200 ppm sampai 500 ppm akan mengalami peningkatan waktu bereaksi, pengurangan memori temporer dan disertai dengan koordinasi yang mulai melemah (Wijaya C, 1995; WHO, 1985)

Toluena dapat dideteksi melalui urin dan darah, dalam urin toluena dapat diperiksa melalui asam hipurat. Pemeriksaan asam hipurat dalam urin merupakan salah satu jenis pemantauan biologik yang penting dalam memulai dan mengukur keterpaparan toluena pada tenaga kerja (NIOSH, 1994). Indeks 


\begin{tabular}{c|c|c}
\hline JURNAL PENELITIAN KESMASY & VOL. 1 NO. 2 & $\begin{array}{c}\text { EDITION: NOVEMBER 2018 - } \\
\text { APRIL 2019 }\end{array}$ \\
\hline \multirow{2}{*}{ RECEIVED: 6 Februari 2019} & http://ejournal.delihusada.ac.id/index.php/JPKSY & ACCEPTED: 20 MARET 2019 \\
\cline { 2 - 3 } & REVISED: 18 FEBRUARI 2019 & ACE
\end{tabular}

terpapar biologis yang masih diperkenankan oleh American of Govermence of Govermental Industrial Hygienists (ACGIHI) adalah $2,5 \mathrm{~g}$ asam hipurat/ gram kreatinin (NIOSH, 1994). Angka rata-rata $2,5 \mathrm{~g} / \mathrm{g}$ kreatinin dalam air kemih yang setara dengan $1,58 \mathrm{~mol}$ asan hipurat permol kreatinin yang dikumpulkan dari kelompok-kelompok pekerja yang terpapar toluena pada akhir jam kerja yang mana ini sesuai dengan tingkat paparan 375 $\mathrm{mg}$ toluena $/ \mathrm{m}^{3}$ udara selama 8 jam, dan keterpaparan 0,947 mol asam hipurat permol kreatinin (1,5 $\mathrm{g} / \mathrm{g})$ juga sesuai dengan keterpaparan sekitar $200 \mathrm{mg} / \mathrm{m}^{3}$ diudara dan menurut National Institute Occupational Safety and Health (NIOSH) yang dapat digunakan sebagai alat pemantauan biologik adalah nilai kadar asam hipurat dalam urin sesudah terpapar oleh toluena dan indeks terpapar biologis yang diperkenankan (NIOSH, 1994; ACGIH, 1993).

Dengan pemakaian toluena dalam jumlah yang banyak pada saat ini maka potensi timbulnya gangguan kesehatan besar pula, oleh karena itu diperlukan identifikasi, evaluasi dan pengendalian terhadap dampak penggunaan toluena tersebut baik di lingkungan kerja maupun pada tenaga kerja.

Para pekerja pengecetan oven otomotif merupakan kelompok yang mempunyai resiko tinggi terhadap bahaya uap toluena karena pemakaian cat sebagai bahan pekerjaan. Dari pengamatan penulis didapat tingkat pengetahuan yang rendah serta perilaku kerja yang buruk terhadap bahaya toluena. Pemeriksaan sesaat pada lingkungan kerja pengecatan oven otomotif dijumpai tingkat paparan uap toluena melebihi $50 \mathrm{ppm}$.

Penelitian yang mendasar mengenai toluena sangat diperlukan karena hasilnya dapat dipergunakan untuk pengembangan cara-cara efektif dalam pemantauan dini terhadap dampak negatifnya pada kesehatan tenaga kerja serta upaya pencegahan penyakit yang diakibatkannya.
Pemakaian toluena di seluruh Indonesia berdasarkan data (BPS, 1996; Deperindag, 1997) adalah sebagai berikut:

Tabel 1. Pemakaian Toluena di Indonesia

\begin{tabular}{lcc}
\hline Tahun & Jumlah (Kg) & Nilai (US\$) \\
\hline $\mathbf{1 9 9 0}$ & 44.061 .498 & 19.204 .191 \\
$\mathbf{1 9 9 1}$ & 50.490 .678 & 26.587 .857 \\
$\mathbf{1 9 9 1}$ & 58.254 .693 & 19.461 .919 \\
$\mathbf{1 9 9 3}$ & 76.011 .863 & 21.974 .855 \\
$\mathbf{1 9 9 4}$ & 79.518 .171 & 26.575 .906 \\
$\mathbf{1 9 9 5}$ & 92.262 .544 & 30.790 .919 \\
$\mathbf{1 9 9 6}$ & 95.592 .758 & 27.211 .822 \\
$\mathbf{1 9 9 7}$ & 93.361 .061 & 31.003 .080 \\
\hline
\end{tabular}

Terpapar toluena yang berasal dari sumbersumber yang dilepaskan ke lingkungan antara lain: Inadvertent Sources (65\%), berupa emisi dari kendaraan bermotor dan pesawat terbang, pemasaran bahan bakar minyak tumpahan yang terdiri atas proses-proses di mana toluena digunakan sebanyak $33 \%$ dan produksi toluena $(2 \%)$ kehilangan pada saat proses dan penyimpanan serta proses emisi (WHO, 1985):

Hasil pengukuran lingkungan harus dibandingkan dengan nilai-nilai standar yang telah disetujui. Hasil ambang batas toluena dari berbagai perkumpulan keselamatan kerja dapat dilihat pada tabel 2 berikut ini (ATSDR, 2003):

Tabel 2. Nilai Ambang Batas (NAB) Toluena

\begin{tabular}{|c|c|c|c|}
\hline No & Perkumpulan & Lingkungan & NAB \\
\hline 1 & ACGIH & $\begin{array}{l}\text { Udara dan } \\
\text { tempat kerja }\end{array}$ & $\begin{array}{c}50 \mathrm{ppm} \\
\left(375 \mathrm{mg} / \mathrm{m}^{3}\right)\end{array}$ \\
\hline 2 & NIOSH & $\begin{array}{l}\text { Udara dan } \\
\text { tempat kerja }\end{array}$ & $\begin{array}{c}100-150 \mathrm{ppm} \\
(375-560 \\
\left.\mathrm{mg} / \mathrm{m}^{3}\right)\end{array}$ \\
\hline 3 & OSHA & $\begin{array}{l}\text { Udara dan } \\
\text { tempat kerja }\end{array}$ & $\begin{array}{c}200 \mathrm{ppm} \\
\left(375 \mathrm{mg} / \mathrm{m}^{3}\right)\end{array}$ \\
\hline 4 & $\begin{array}{l}\text { US. Environmental } \\
\text { Protection Agency }\end{array}$ & Air minum & $1 \mathrm{ppm}$ \\
\hline 5 & $\begin{array}{l}\text { Menteri Tenaga } \\
\text { Kerja No. } \\
\text { SE01/MEN/1997 }\end{array}$ & $\begin{array}{l}\text { Udara dan } \\
\text { tempat kerja }\end{array}$ & $50 \mathrm{ppm}$ \\
\hline
\end{tabular}




\begin{tabular}{c|c|c}
\hline JURNAL PENELITIAN KESMASY & VOL. 1 NO. 2 & $\begin{array}{c}\text { EDITION: NOVEMBER 2018 - } \\
\text { APRIL 2019 }\end{array}$ \\
\hline \multirow{2}{*}{ RECEIVED: 6 Februari 2019} & http://ejournal.delihusada.ac.id/index.php/JPKSY & ACCEPTED: 20 MARET 2019 \\
\cline { 2 - 3 } & REVISED: 18 FEBRUARI 2019 & ACI
\end{tabular}

\section{METODE PENELITIAN}

Penelitian ini dilakukan pada dua bengkel (Acapella) tempat pengecetan oven otomotif yang berada di kecamatan Medan Timur, yaitu yang terletak di jalan M.H. Thamrin kelurahan Sidodadi kecamatan Medan Timur dengan jumlah tenaga kerja 20 orang yang terdiri dari 10 orang di bagian pengecetan dan 10 orang di bagian pengelasan, dengan luas areal $\pm 1200 \mathrm{~m}^{3}$ dan yang terletak di jalan Bilal kecamatan Medan Timur dengan jumlah tenaga kerja 10 orang yang terdiri dari 5 orang di bagian pengecetan dan 5 orang di bagian pengelasan, dengan luas areal \pm 1500 $\mathrm{m}^{3}$. Yang diambil sebagai sampel dalam penelitian ini adalah pekerja yang terlibat langsung dalam proses pengecatan dan memenuhi kriteria yang ada pada kuesioner.

Penelitian ini dilakukan selama 6 bulan pada tahun 2018. Penelitian ini merupakan studi pra-eksperimental dengan pretest-posttets design yang bertujuan untuk mengevaluasi program pencegahan kecelakaan kerja yang dilakukan dengan membandingkan hasil metabolit di urin sebelum dan sesudah terpapar toluena pada satu kelompok tenaga kerja di dalam satu populasi.

Populasi pada penelitian ini adalah semua pekerja di tempat pengecatan oven otomotif yang terpapar toluena di kecamatan Medan Timur. Sampel di ambil dari populasi terjangkau dengan cara purposive sampling dan diperoleh sebanyak 12 orang (Sastroasmoro, 2002). Subyek penelitian yang diambil diseleksi terlebih dahulu dengan memperhatikan kriteria yang telah ditentukan.

Kriteria inklusi sampel adalah bila subyek penelitian bersedia ikut dalam penelitian ini dengan persetujuan lisan dan tertulis, bersedia mengikuti wawancara, pemeriksaan fisik dan pemeriksaan laboratorium (urin). Kriteri eksklusi sampel adalah bila subyek penelitian terpapar toluena di luar jam kerja, mempunyai riwayat, antara lain berumur lebih dari 40 tahun, memakai obat yang mempengaruhi kerja (cytochorme P-450), dan mempunyai riwayat alkoholik.

Pemeriksaan kadar uap toluena di lingkungan kerja dilakukan dengan metode 1501, Issue 2 dari NIOSH, dengan bantuan alat kromatografi gas. Alat-alat yang digunakan untuk mendapatkan sampel uap toluena di lingkungan kerja adalah pipa pengadsorpsi karbon aktif (chacod) dan pompa pengisap dengan kecepatan aliran udara 1 liter/menit. Waktu pengambilan sampel adalah selama 1 jam. Metode ini dapat mendeteksi hidrokarbon aromatik, khususnya toluena dengan ketelitian sampai 90,1\% (NIOSH, 1994). Cara mengukur kadar uap toluena dengan menggunakan kromatografi gas adalah sebagai berikut (NIOSH, 1994)

Pemeriksaaan kadar kreatinin urin dilakukan dengan metode Jaffe tanpa deproteinisasi, dan menggunakan alat baca spektrofotometer Hitachi 737, yang dibaca pada panjang gelombang $570 \mathrm{~nm}$ (Boehringer Mannheim). Pengambilan sampel urin di lakukan pada hari senin sebelum kerja (pukul 08.00) dan sore hari akhir jam kerja (pukul 16.30 - 17.00), lalu dianalisis di Laboratorium Balai Hiperkes dan Kesehatan Kerja Departemen Tenaga Kerja untuk kadar asam hipurat urin di Laboratorium R.S.H. Adam Malik untuk kreatinin urin.

Analisis data dilakukan terhadap 12 subjek penelitian yang dikumpulkan, terdiri dari 8 subjek penelitian di bengkel $A$ dan 4 subjek penelitian di bengkel $B$.

\section{HASIL PENELITIAN}

Dari hasil observasi dan wawancara langsung didapatkan bahwa pihak manajemen tempat pengecatan oven otomotif tidak memberikan perhatian khusus terhadap program kesehatan dan keselamatan kerja, hanya menyuruh pekerja yang sakit pergi ke dokter praktek atau balai pengobatan swasta.

Pemeriksaan kadar bahan kimia di udara lingkungan kerja tidak pernah dilakukan oleh pihak manajemen, begitu juga pemeriksaan laboratorium untuk perawatan biologik. Pemakaian alat pelindung diri tidak digunakan 


\begin{tabular}{c|c|c}
\hline JURNAL PENELITIAN KESMASY & VOL. 1 NO. 2 & $\begin{array}{c}\text { EDITION: NOVEMBER 2018 } \\
\text { APRIL 2019 }\end{array}$ \\
\hline \multirow{2}{*}{ RECEIVED: 6 Februari 2019} & http://ejournal.delihusada.ac.id/index.php/JPKSY & \multirow{2}{*}{ ACCEPTED: 20 MARET 2019 } \\
\cline { 2 - 3 } & REVISED: 18 FEBRUARI 2019 &
\end{tabular}

sebagaimana yang direkomendasikan pemerintah. Masker yang dipakai hanya masker kain.

Pengukuran kadar uap toluena di lingkungan kerja dilakukan 4 jam setelah pengecatan berlangsung dan dilakukan di ruang lingkup pengecatan oven otomotif. Kadar uap toluena di lingkungan kerja yang terpapar langsung pada bengkel A didapat $662,85 \mathrm{ppm}$ dan pada bengkel $B$ terdapat 58,92 ppm.

Karakteristik subjek penelitian (responden) terkait umur ditunjukkan oleh tabel 3 berikut.

Tabel 3. Karakteristik Responden

\begin{tabular}{ccc}
\hline $\begin{array}{c}\text { Kelompok Umur } \\
\text { (Tahun) }\end{array}$ & $\mathrm{N}$ & $\%$ \\
\hline$\leq 18$ & 1 & 8,3 \\
$19-25$ & 8 & 66,67 \\
$26-32$ & 1 & 8,3 \\
$33-39$ & 2 & 16,67 \\
\hline
\end{tabular}

Dari tabel di atas, dapat dilihat bahwa umur responden terbanyak adalah antara umur 1825 tahun yaitu sebanyak 8 orang $(66,67 \%)$.
Hasil uji $\mathrm{t}$ berpasangan menunjukkan nilai mean asam hipurat urin para pekerja antara pengukuran pagi dan sore hari mempunyai perbedaan yang bermakna (tabel 4).

Tabel 4. Rerata Kadar Asam Hipurat Urin Responden pada Pagi dan Sore Hari

\begin{tabular}{lccc}
\hline & \multicolumn{2}{c}{ Kadar Asam $(\mathrm{g} / \mathrm{g})$} & \\
\cline { 2 - 3 } Waktu & Mean & $\mathrm{SD}$ & $p$ \\
\hline Pagi & 1,68 & 0,978 & 0,004 \\
Sore & 5,03 & 4,159 & \\
\hline
\end{tabular}

Pada tabel 5. dapat dinyatakan bahwa variabel tingkat pendidikan dikeluarkan dari model regresi dengan $p$-value sebesar 0,850 yang menunjukkan adanya hubungan yang positif antara variabel umur, masa kerja dengan kadar asam hipurat/kretinin urin (dimana nilai koefisian B positif). Variabel umur dan masa kerja mempunyai peranan dalam menentukan kadar asam hipurat, dimana variabel masa kerja mempunyai perananan yang lebih besar daripada variabel umur (dimana nilai Beta $0,746>0,285$ ).

Tabel 5. Hasil Analisis Korelasi dan Regresi

\begin{tabular}{|c|c|c|c|c|c|}
\hline \multirow[b]{2}{*}{ Variabel } & \multicolumn{4}{|c|}{ Analisis Data } & \multirow[b]{2}{*}{$p$} \\
\hline & $r$ & R Square & $B$ & Beta & \\
\hline Umur & 0,993 & 0,985 & 1,336 & 0,285 & 0,003 \\
\hline Tingkat Pendidikan & - & - & $-0,041$ & $-0,009$ & 0,850 \\
\hline Masa Kerja & 0,993 & 0,985 & 2,862 & 0,746 & 0,000 \\
\hline
\end{tabular}

\section{Pembahasan}

Penelitian terhadap kadar uap toluena di lingkungan kerja bengkel pengecetan oven otomotif 4 jam setelah terpapar langsung, menunjukkan kadar uap toluena yang tinggi, yaitu 62,85 ppm pada bengkel A dan 58,92 ppm pada bengkel $B$. Nilai tersebut berada diatas ambang batas aman menurut standar keselamatan dan kesehatan kerja. Walaupun beberapa perkumpulan keselamatan dan kesehatan kerja di negara lain menetapkan kadar 100 ppm masih dianggap aman untuk para pekerja, tetapi di Indonesia dalam ketentuan Menteri Tenaga Kerja No. SE 01/MEN/97 menetapkan $50 \mathrm{ppm}\left(375 / \mathrm{m}^{3}\right)$ sebagai ambang batas aman kadar uap toluena (Depnaker RI, 2000). Pengendalian tersebut berupa pengukuran pajanan di tempat kerja serta pengendalian teknis, administratif maupun penggunaan Alat Pelindung Diri (APD).

\section{Manajemen kesehatan dan keselamatan kerja di tempat pengecetan oven otomotif}

Penelitian terhadap manajamen kesehatan dan keselamatan kerja pada kedua bengkel pengecatan oven otomotif di kesehatan Medan Timur kota Medan menunjukkan bahwa perhatian terhadap program kesehatan dan keselamatan kerja, khususnya usaha untuk mencegah terjadinya efek samping akibat paparan uap toluena yang tinggi terhadap 


\begin{tabular}{|c|c|}
\hline IASY & \\
\hline & http://ejournal.de \\
\hline $\begin{array}{l}\text { RECEIVED: } 6 \text { Februari } 2019 \\
\text { para pekerja belum mema } \\
2000), \text { mengharuskan } \\
\text { menggunakan toluena } \\
\text { bekerjaan, untuk me } \\
\text { eelindungan diri kepada para }\end{array}$ & $\begin{array}{lr}\text { (BOC } & \text { REVISE } \\
\text { Isahaan } & \text { yang } \\
\text { bagai } & \text { bahan } \\
\text { jerikan alat } \\
\text { ekerja. }\end{array}$ \\
\hline $\begin{array}{l}\text { Pengelolaan manajemen } \\
\text { dilakukan melalui perbaika } \\
\text { yang meliputi pengatur } \\
\text { pemberian suplemen ma } \\
\text { mengandung anti oksidan } \\
\text { raga yang teratur bagi } \\
\text { informasi dan edukasi ke }\end{array}$ & $\begin{array}{l}\text { juga dapat } \\
\text { k manajemen } \\
\text { vaktu kerja, } \\
\text { bergizi dan } \\
\text { program olah } \\
\text {; pemberian } \\
\text { ekerja dalam } \\
\text { erilaku hidup }\end{array}$ \\
\hline
\end{tabular}

\section{Rerata kadar asam hipurat urin responden}

Pada penelitian ini dijumpai rerata kadar asam hipurat urin para pekerja pada pagi hari masih berada pada ambang batas normal $(1,68 \mathrm{~g} / \mathrm{g})$, walaupun ada beberapa pekerja yang mempunyai kadar yang jauh diatas nilai ambang normal. Pada sore hari, dijumpai rerata kadar asam hipurat urin berada diatas nilai ambang normal $(5,03 \mathrm{~g} / \mathrm{g})$. Pada penelitian ini dijumpai kenaikan yang bermakna kadar asam hipurat urin para pekerja yang diperiksa pagi dan sore hari. Kenaikan asam hipurat pada sore hari terjadi setelah para pekerja terpapar oleh uap toluena lebih dari 50 ppm. Pengukuran yang menandakan adanya keterpaparan terhadap uap toluena adalah kadar lebih dari $2,5 \mathrm{~g} / \mathrm{g}$ dari urin yang diambil pada akhir jam kerja (ATSDR, 2003).

Jika seseorang terpapar Benzena maupun toluena maka dapat menyebabkan kegagalan sel induk mieloid yang mengakibatkan berkurangnya produksi hemoglobin dan sel darah merah dan akibat dari kekurangan sel darah merah yang terjadi dalam waktu lama akan dapat menyebabkan anemia aplasti (Robbins \& Kumar, 1995). Namun banyak penelitian telah mempercayakan pengukuran kadar toluena yang belum dimetabolisme seperti pada pernapasan, dalam darah atau urin sama baiknya dengan mengukur metabolit dalam urin (Peter et al., 2000).

Pitarque, dkk (1999) menemukan bahwa kadar asam hipurat urin pekerja yang terpapar uap toluena lebih tinggi dari pekerja yang tidak terpapar (Pitarque M, 1999). Kelompok yang terpapar toluen, kadar asam hipuratnya lebih tinggi daripada kelompok yang tidak terpapar (Decharat, 2014). Pada penelitian ini tidak dicatat beberapa lama para pekerja terpapar oleh toluena pad 1 hari kerja tersebut. The America Conference of Governmental Industrial Hygienest (ACGIH) menentukan waktu 8 jam merupakan nilai ambang batas terpapar akut (ATSDR, 2003). Namun demikian, akibat dari terpapar toluena di udara (Kurang dari 100 ppm) tidak menyebabkan resiko iritasi mata (Irmasari, 2018) tetapi paparan toluen 1-80 ppm dengan rata-rata paparan $15 \mathrm{ppm}$ dapat menyebabkan gangguan seperti sakit kepala, mual, dan muntah (Alfaro dkk, 2011; Agustina \& Mukono, 2017).

\section{Hubungan asam hipurat urin dengan umur, tingkat pendidikan dan masa kerja responden}

Dari analisis selanjutnya, dijumpai bahwa faktor umur dan masa kerja mempunyai pengaruh untuk memprediksi kadar asam hipurat dalam urin, sementara tingkat pendidikan tidak mempengaruhi. Pengaruh tersebut mempunyai arah positif, dimana asam hipurat akan naik sebesar $1,336 \mathrm{~g} / \mathrm{g}$ bila pekerja mempunyai kelompok usia yang lebih tua setelah dikontrol faktor masa kerja. Makin tua usia pekerja memperlihatkan kadar asam hipurat urin yang lebih tinggi. Keadaan ini mungkin disebabkan oleh faktor usia yang berperan dalam kemampuan metabolisme toluena dalam tubuh.

Asam hipurat urin akan meningkat 2,862 $\mathrm{g} / \mathrm{g}$ bila pekerja mempunyai kelompok masa kerja yang lebih besar setelah dikontrol faktor umur. Hal ini terlihat pada kelompok pekerja yang telah bekerja lebih dari 5 tahun, kadar asam hipurat urin pagi telah melewati ambang batas $2,5 \mathrm{~g} / \mathrm{g}$. Keadaan ini menunjukkan lamanya waktu terpapar dengan uap toluena akan menyebabkan akumulasi toluena dalam darah dan kemudian diekskresikan melalui urin dalam bentuk asam hipurat dengan jumlah yang tinggi.

Para pekerja yang terpapar uap tolueana dengan masa kerja rata-rata 5,7 tahun dengan ringkasan $88 \mathrm{ppm}$ per jam kerja, menjumpai kadar asam hipurat urin lebih tinggi 


\begin{tabular}{|c|c|}
\hline \multicolumn{2}{|l|}{ JURNAL PENELITIAN KESMASY } \\
\hline \multicolumn{2}{|r|}{ nal delit } \\
\hline \multicolumn{2}{|l|}{ RECEIVED: 6 Februari 2019} \\
\hline \multirow{2}{*}{\multicolumn{2}{|c|}{$\begin{array}{l}\text { dibandingkan kelompok kontrol (US EPA, } \\
\text { 1994). Kemudian, diperhitungkan bahwa } \\
\text { faktor masa kerja merupakan variabel yang } \\
\text { mempunyai peranan lebih besar daripada } \\
\text { variabel umur terhadap penentuan kadar asam }\end{array}$}} \\
\hline & \\
\hline $\begin{array}{l}\text { hipurat urin para pe } \\
\text { menumbuhkan penelitian let }\end{array}$ & $\begin{array}{l}\text { ja. Hal ini } \\
\text { anjut. }\end{array}$ \\
\hline
\end{tabular}

\section{KESIMPULAN}

Hasil penelitian ini menunjukkan bahwa:

1. Perhatian terhadap program kesehatan dan keselamatan kerja, khususnya usaha untuk mencegah terjadinya efek samping akibat paparan uap toluena masih rendah.

2. Rerata kadar asam hipurat urin para pekerja pada pagi hari masih berada pada ambang batas normal $(1,68 \mathrm{~g} / \mathrm{g})$, dan meningkat pada sore hari $(5,03 \mathrm{~g} / \mathrm{g})$ walaupun ada beberapa pekerja yang mempunyai kadar yang jauh diatas nilai ambang normal.

3. Variabel umur dan masa kerja mempunyai peranan dalam menentukan kadar asam hipurat, dimana variabel masa kerja mempunyai perananan yang lebih besar daripada variabel umur.

\section{DAFTAR PUSTAKA}

Agency for Toxic Subtance and Disease Registry (ATSDR). 2003. Toluene toxicity. US Departement of Health and Human Services, Public Health Service.

Agustina, U., \& Mukono, J. 2017. Keluhan Sistem Saraf Pusat Pada Pekerja Yang TerpaparToluen Di Udara Di Bengkel Pengecatan Mobil Di Surabaya. Jurnal Kesehatan Lingkungan Vol. 9 (1) p: 3139.

Alfaro-Rodríguez, A., Bueno-Nava, A., GonzálezPiña, A., Arch-Tirado, E., Vargas-Sánchez, J. \& Ávila-Luna, A. 2011. Chronic exposure to toluene changes the sleep-wake pattern and brain monoamine content in rats. Acta Neurobiologiae Experimentalis, vol. 71 (2) pp. 183-192.

American Conference of Govermental Industrial Hygienists. 1993. Treshold limit values for chemical substances in work enviromenment and biological exposure indices 1993-1994. Cinciaiti: American Conference of Govermental Industrial Hygienist.

Bavazzano P, Perico A, Lidoni V, Colzi A. 1994. Occupational exposure and individual factors infleencing urinary elimination of hippuric acid. G Ital med Lav., 16: 5761.

Biro Pusat Statistik. 1996. Statistik perdagangan luar negeri Indonesia. Jilid 1. Impor. Jakarta: Biro Pusat Statistik.

BOC Gases. 2000. Material Safety data sheet. Boehringer Mannheim. Creatinine jaffe method. BM/Hitachi 747/743 (Brosur).URL: http://www.google.com/MSOS/G453.ht $\underline{\mathrm{ml}}$.

Decharat S. (2014). Urinary Hippuric Acid and Toluene Levels in Workers of Printing Factories in Thailand. Thailand. Thaksin University. diakses di http://ijoh.tums.ac.ir

Departemen Tenaga Kerja RI. 2000. Tata cara pengjuan, penilaian dan pemberian penghargaan kecelakaan nihil (zero accident award).

Handoyo, E. \& Wispriyono, B. 2016. Risiko Kesehatan Pajanan Benzena, Toluena, Dan Xylena Petugas Pintu Tol. Jurnal Kesehatan Masyarakat, Vol. 11 (2).

Hjelm EW, Lof A, Sato A, Comsjo A, Lundmark MO, Norstrom A. 1994. Dietary and ethanol induces alterations of the toxicokineties of toluene in humans. Occup environ., 51. 487-91.

Irmasari, F. 2018. Kadar Toluen Di Udara Lingkungan Kerja Berkorelasi Terhadap Kadar Asam Hipurat Urine Pada Pekerja Percetakan Di Rungkut Surabaya. Jurnal Kesehatan Lingkungan, Vol. 10 (3).

Kawai T, Mizunoma K, Okada Y, Horiguchi S, Ikada M. 1996. Toluena itself as the 


\begin{tabular}{|c|c|c|c|}
\hline JURNAL PENELITIAN KESMASY & \multicolumn{2}{|c|}{ VOL. 1 NO. 2} & $\begin{array}{l}\text { TION: NOVEMBER } 2018- \\
\text { APRIL } 2019\end{array}$ \\
\hline & \multicolumn{2}{|c|}{ http://ejournal.delihusada.ac.id/index.php/JPKSY } & \\
\hline RECEIVED: 6 Februari 2019 & \multicolumn{2}{|c|}{ REVISED: 18 FEBRUARI 2019} & CEPTED: 20 MARET 2019 \\
\hline $\begin{array}{l}\text { best urinary marker } \\
\text { exposure. Int arch } \\
\text { health; 68: } 289-97 .\end{array}$ & $\begin{array}{c}\text { of toluenaa } \\
\text { occup environ }\end{array}$ & $\begin{array}{l}\text { Jakarta: Pusat } \\
\text { Kesehatan dan } \\
\text { Depnaker. }\end{array}$ & $\begin{array}{l}\text { Pelayanan Ergonomi } \\
\text { Keselamatan Kerja }\end{array}$ \\
\hline
\end{tabular}

Martin KA. 2001. Toxicity, toluene. Department of Emergency Medicine, The Toledo Hospitasl, 2001.

National Institute for Occupational Safety and health (NIOSH). 1994. Manual of analytical methods. Hippuric and methyl hippuric acids in urine, diakses dari: URL:

http://www.cdc.gov/NIOSH/8301.html

National Institute for Occupational Safety and health (NIOSH). 1994. Manual of analytical methods. Hydrocarbons, aromatic. Diakses dari http://www.cdc.gov/NIOSH/1501.html

Peter, P.E. Rogelio, T.V., Stephen, M.R. 2000. Environmental, and Biological Monitoring of Benzene during SelfService Automobile Refueling. Environmental Health Perspectives, Vol. 108 (12).

Pitarque $M$, Vaglenov $A$, Nosko $M$, Hirvonen $A$, Norppa H, Creus A, et al. 1999. Evaluation of DNA damage by comet essay shoe warkers exposed of toluene and other organic solvents. Mutat Res; 441 (1): 115-27.

Pusat data Departemen Perindustrian dan Perdagangan Republik Indonesia. 1997. Data ekspor impor tahun 1990 sampai 1997 (data komputer)

Robbins \& Kumar. 1995. Buku Ajar Patologi 1. Jakarta: EGC.

Sastroasmoro S. 2002. Pemilihan subyek penelitian. Dalam: Sastroasmoro $\mathrm{S}$, Ismael $\mathrm{S}$, penyunting.Dasar-dasar metodologi penelitian klinis. Edisi ke-2. Jakarta: Sagung Seto.

Soeripto M. 1995. Pedoman penerapan hiperkes dan keselamatan kerja untuk sektor industri automotif. Proyek Higiene Perusahaan dan Kesehatan Kerja tahun 1995-1996. Edisi ke-2.
U.S Environmental Protection Agency (US.EPA). 1994. Integrated risik information system (IRIS) database. Reference concentration (RfC) for toluena. Diakses dari: URL: http://www.epa.gov.IRIS/Subst/0118.ht $\underline{\mathrm{m}}$

Wea YN. 2003. Kebijakan pemerintah di bidang keselamatan dan kesehatan kerja (K3) dalam era globalisasi. Dalam: Eyanoer HF, Syam B, Nasution A, Siregar $A B$, Gunawan, penyunting. Prosiding seminar nasional pelaksanaan dan kesehatan kerja (K3) dalam menghadapi OTDA dan AFTA 2003. Medan: Ikatan Mahasiswa Magister Kesehatan Kerja Program Pascasarjana Universitas Sumatera Utara.

Wijaya C. 1995. World Health Organization: Deteksi dini penyakit akibat kerja. Edisi ke-2. Jakarta: Penerbit buku kedokteran EGC.

World Health Organization. 1985. International Programme on Chemical Safety (IPCS) Environmental health critria 52 toluena. Geneva: World Health Organization.

Zenz C, Dickerson OB, Horvath EP, 1994. Occupational medicine, Edisi ke-3. St. Louis: Mosby Year Book Inc. 